University of Baghdad

College of Engineering

(U)

JOURNAL OF ENGINEERING
Journal of Engineering

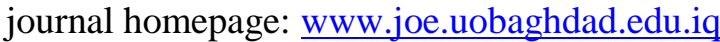

Number 4 Volume 26 April 2020

Mechanical and Energy Engineering

\title{
Aerodynamic Characteristics Comparison between Spiroid and Blended Winglets
}

\author{
Dalya Adnan Abd \\ Researcher \\ College of Engineering-University of Baghdad \\ Dalyaadnan1990@gmail.com
}

\author{
Dr. Anmar H. Ali \\ Lecturer \\ College of Engineering-University of Baghdad \\ aha_has@yahoo.com
}

\begin{abstract}
A numerical and experimentally investigation for two types of winglets (spiroid and blended), which are used to reduce the induced drag caused by the trailing vortices were presented and discussed in this work. The SOLIDWORK 2016 was used to model a rectangular wing geometry of NACA2415 cross-sectional airfoil with blended and spiroid airfoils (2415 and 0012). The steady, incompressible N.S equations with standard $(\kappa-\omega)$ turbulence model were simulated and solved by ANSYS FLUENT 18.0 for turbulent flow. The three-dimensional printer was used to manufacture the models in the experimental work. The present work focused on the difference between two types of winglets of aircraft which are performed in a low-speed wind tunnel of $55 \mathrm{~m} / \mathrm{s}$ maximum speed and $(0.7 \mathrm{~m} \times 0.7 \mathrm{~m} \times 1.5 \mathrm{~m})$ rectangular test section. The flow field and the aerodynamic characteristics of lift coefficient, drag coefficient, pitching and bending moment coefficient were investigated with lift to drag ratio for different angles of attack numerically and experimentally at Reynolds number of $3.72 \times 10^{5}$. The results show that in general, the maximum lift to drag ratio for two winglet configurations for 6 angle of attack is $20 \%$ different for blended winglets as compared with spiroid winglets. The results show that the blended winglet is more effective than spiroid winglet at low angles of attack, but for high angles the spiroid winglet is.
\end{abstract}

Keywords: Winglet, wingtip vortices, Aerodynamic characteristics.

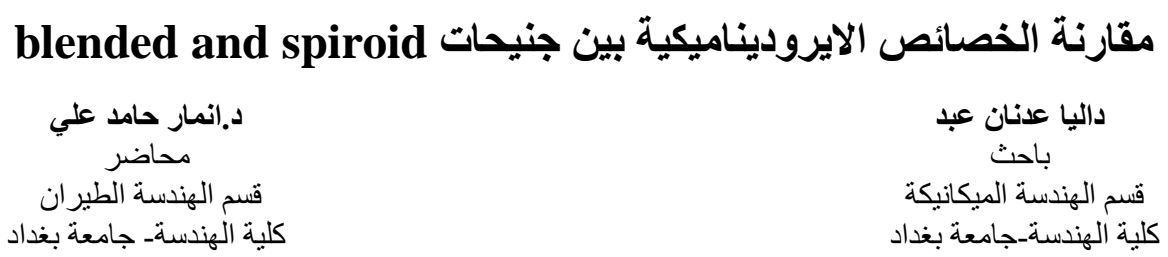

\section{الخلاصة}

تمت الدر اسة العددية و التجريبية لنو عين من الجنيحات (spiroid and blended و التي تستخدم لتقلل الممانعة الحثية الناجمة

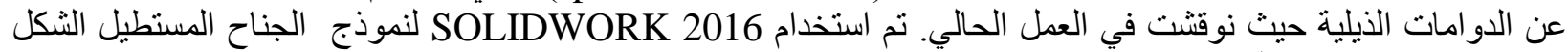

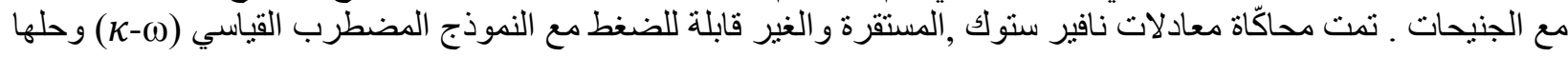

\footnotetext{
*Corresponding author
}

Peer review under the responsibility of University of Baghdad.

https://doi.org/10.31026/j.eng.2020.04.03

2520-3339 (C) 2019 University of Baghdad. Production and hosting by Journal of Engineering.

This is an open access article under the CC BY4 license http://creativecommons.org/licenses/by /4.0/).

Article received: $16 / 5 / 2019$

Article accepted:28/5/2019

Article published:1/4/2020 


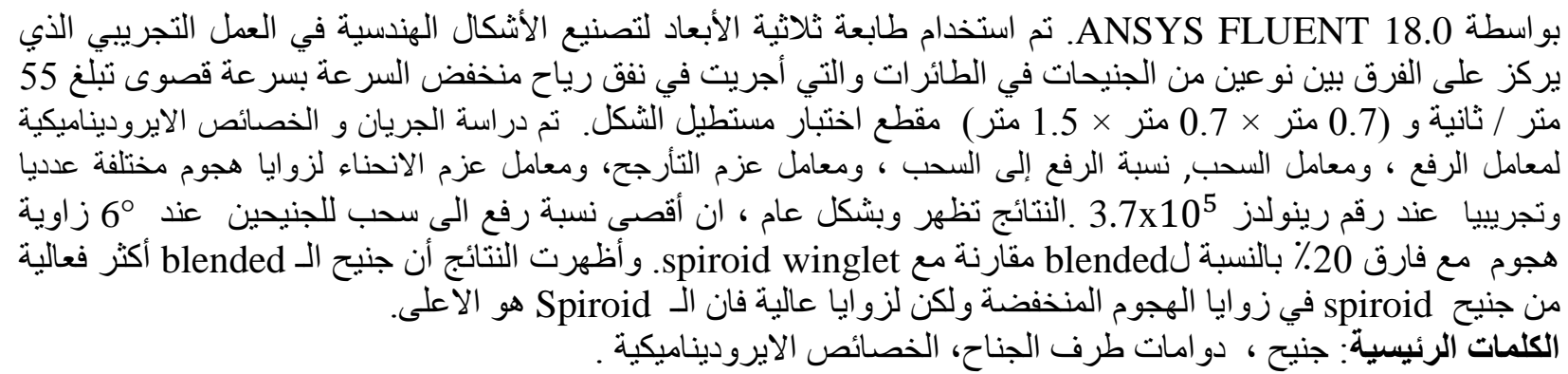

\section{INTRODUCTION}

The Induced drag is caused by the lift force generated by the wing. The trailing vortices which are produced at the tips of the wing, try to make a downwash velocity along the span of the wing. The magnitude of induced drag depends on the amount of lift force being generated by the wing and on the shape and size of the wing.

The skin friction and induced drag for typical civilian transport aircraft, representing more than $80 \%$ of total drag at cruising conditions. The induced drag is one of the major contributors (about $35 \%$ ) of the total drag ( Soltani, et al., 2004); fuel consumption is an important factor in the aircraft. The winglet is a vertical or angled extension at the wingtips, which is used to improve aircraft efficiency by decreasing the induced drag in lift-to-drag ratio (L/D), also it increases the effective aspect ratio of the wing without increasing loads structure but there are drawbacks for winglets which increases the structure fixation of the wing, flutter, and fatigue. There are several types of winglets, such as (Fence winglet, Raked winglet, Wing-grid winglet, etc.) which are used for different manners, but they are always working to reduce induced drag by partial recovery tip vortex energy. A span extension might be lowering the induced drag due to lift, but it would be an increase in the parasitic drag and structure at the fixing requirement, another point a limiting span may be attributed to the airport gates. In 1976, Richard Whitcomb experimentally developed the concepts of winglets in the NASA Research Centre. A wing with winglet was compared with a simple extension span. The winglet showed $20 \%$ reduction in the induced drag and $9 \%$ increase in the wing lift to the drag ratio.

(Guerrero, et al., 2012) had studied numerically the spiroid winglet for swept wing of NACA2412 cross-section and sweep angle $30.1^{\circ}$. The results showed, a reduction in the induced drag and an increasing in the lift coefficient for the wing, at $\mathrm{CL}=0.40,28.0 \%, \mathrm{CL}=0.55,35.0 \%$ and $\mathrm{CL}=0.95,75.0 \%$. For $5.0^{\circ}$ angle of attack the ratio (CL/CD) $\max$ was approximately $7.1 \%$. A rectangular wing with blended winglet had been investigated by (Beechook and wang., 2013). The analysis at various cant angles $0^{\circ}, 30^{\circ}, 45^{\circ}$ and $60^{\circ}$ (the angles measured from the horizontal axis) had been studied numerically and experimentally. The results showed that the ratio (L/D) for the wing with winglet at cant angles $45^{0}$ gave a better performance as compared to others. The numerical analysis of the aerodynamic characteristics for the rectangular wing of (NACA6518 airfoil section) was studied by (Helal, et al., 2016) with blended winglet for various cant angles $\left(30^{\circ}, 45^{\circ}, 60^{\circ}, 90^{\circ}\right)$, which is measured by the horizontal axis. The results showed that the increase in the lift to drag ratio was from $3 \%$ to $15 \%$ as compared to the clearwing also the best angle of attack was $4^{\circ}$ for cant angle $90^{\circ}$.

(Bada, et al., 2016) studied the spiroid and dual feather winglets for the of BOEING 737 wing using FLUENT commercial program. The aerodynamic characteristics and the performance of the winglet had been studied numerically. The results showed that the spiroid winglet was a better performance than dual feather. The lift to drag ratio L/D for spiroid winglet at $0^{\circ}$ angle of attack was 19.99 and for dual feather was12.26. A computational analysis for the swept-back wing with blended winglet with cant angle $30^{\circ}, 60^{\circ}, 90^{\circ}$ had been investigated by (Shamil, et 
al., 2018) the result showed that for angle of attack less than $0^{\circ}$, the blended winglet had been the maximum CL/CD at $90^{\circ}$ cant angle, while when angle of attack is $0^{\circ}$ to $4{ }^{\circ}, \mathrm{CL} / \mathrm{CD}$ was maximum for cant angle $60^{\circ}$ and at angle of attack greater than $4^{\circ}$ the CL/CD was maximum at cant angle $30^{\circ}$.

In the present work, the aerodynamic characteristics and flow field will be studied for the rectangular wing with spiroid and blended winglet numerically and experimentally. The blended winglet is attached to the wingtips of the wing with smooth curve between them, which decreases the interference drag at the wing junction with winglet, and the spiroid winglet forms a closed loop, half chord extends vertically, and other half extends horizontally to join in spiral loop at the wingtip. A comparison between them will be presented to find the best performance of the two types of winglets.

\section{NUMERICAL SOLUTION}

A rectangular wing with NACA2415 and two types of winglet had been modeled using SOLIDWORKS 2016 Design Modular. Only half geometry had been studied in the present work due to the symmetry of the right and the left sides of the wing. The symmetrical plane may be represented geometrically by $\mathrm{x}-\mathrm{y}$ plane, and the $\mathrm{z}$-axis is the spanwise of the right-hand side of the wing as viewed from the front.

The rectangular wing of the five aspect ratio had been used in the present work. The geometrical specifications of the wing are shown in Table 1.

Fig.1 and Fig. 2 show the geometrical description of the spiroid and the blended winglets.

Table 1. Rectangular Wing Specifications.

\begin{tabular}{|c|l|l|}
\hline NO & Description & \multicolumn{1}{|c|}{ Dimension } \\
\hline 1 & Airfoil Type & NACA 2415 \\
\hline 2 & Aspect Ratio & 5 \\
\hline 3 & Chord & $18 \mathrm{~cm}$ \\
\hline 4 & Wing Span & $90 \mathrm{~cm}$ \\
\hline
\end{tabular}



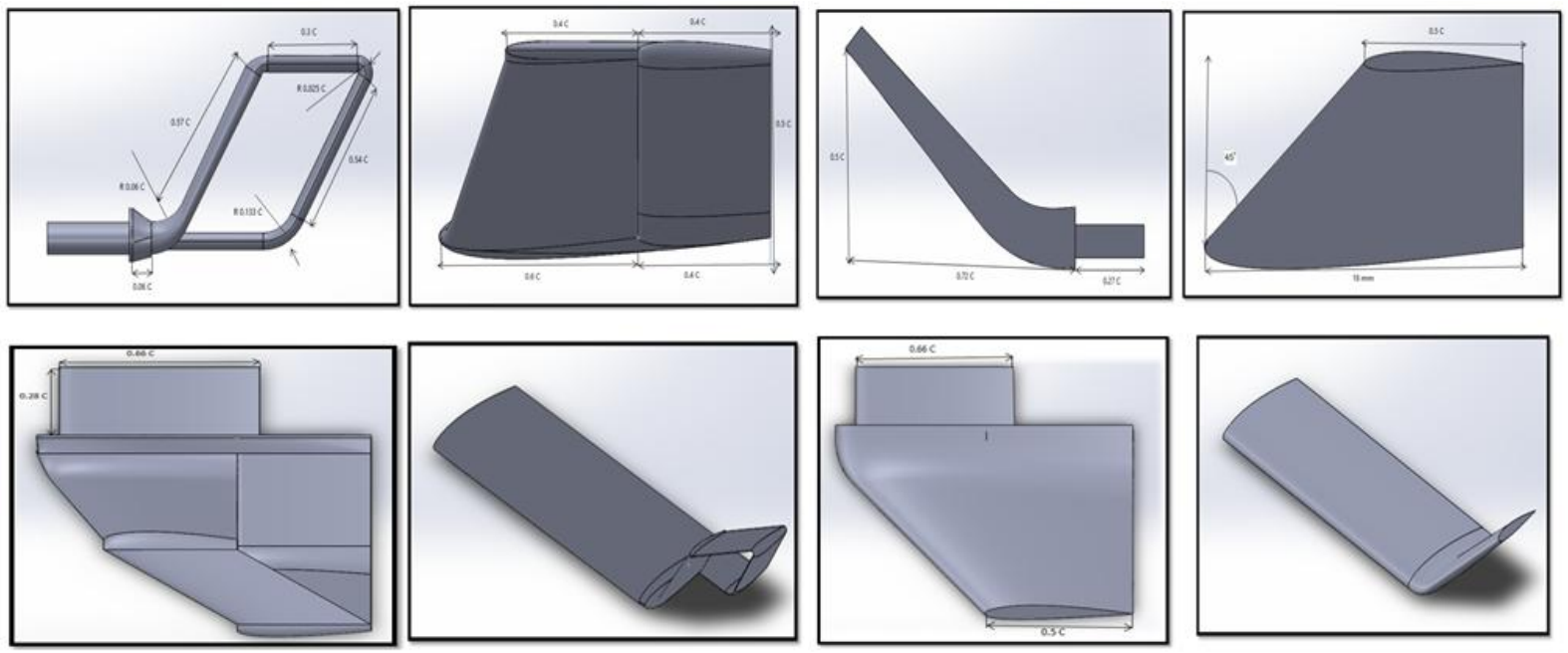

Figure 1. The spiroid winglet.

Figure 2. Blended winglet.

The Computational Fluid Dynamics by FLUENT ANSYS 18 had been used to analysis the rectangular wing with two winglets (spiroid and blended).

Three important stages must be simulated to find the final results. The first one is the preprocessing stage, where the geometrical details were imported from SOLID WORKS software, as stated previously. The computational domain and its discretization were modeled by ANSYS FLUENT software. The C- domain was prepared concerning the characteristics chord length of the wing. The front, behind, upper, and lower lengths are $12.5 \mathrm{c}, 20 \mathrm{c}, 12.5 \mathrm{c}$ respectively, and one span length for the right plane of the domain, as stated by (Beechook and Wang, 2013) and is shown in Fig. 3. The number of cells has been examined between 5,000,000 cells to 6,500,000 cells. The chosen total number of grids is about 5750000 cells more or less for the types of winglets; which is selected through grid independence test (Fig 4). A threedimensional unstructured tetrahedral mesh was used to compute the flow around the modes as shown in Fig 5.

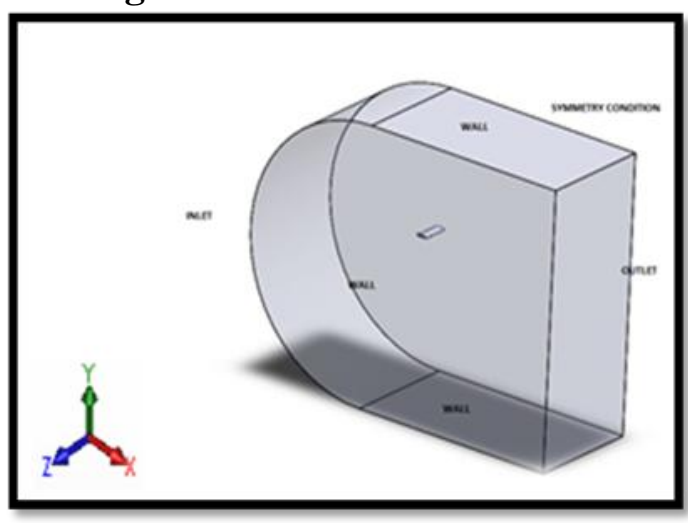

Figure 3. Computational Domain and boundary Condition.

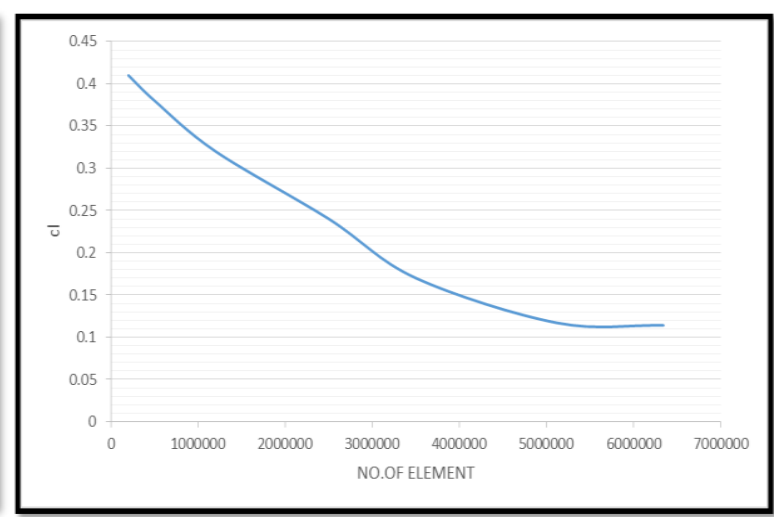

Figure 4. The Grid Independence Test. 


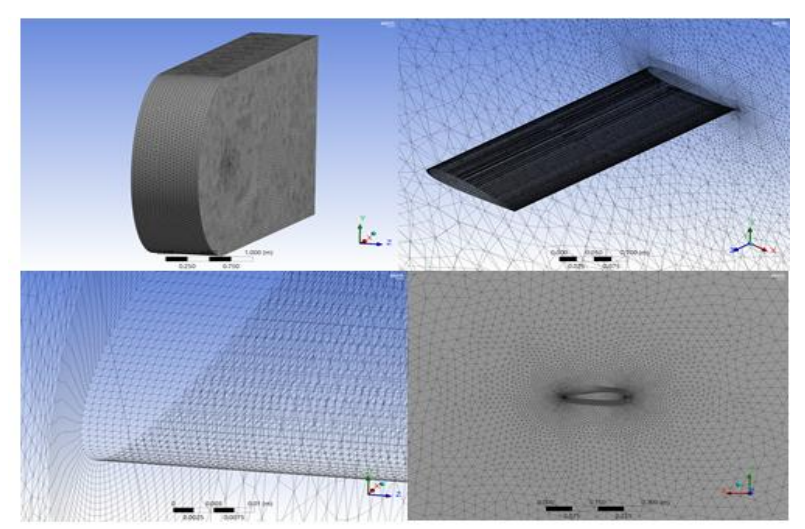

Figure 5. The domains with wing model mesh and the inflation meshing.

The used assumptions for the working fluid were steady, three dimensional subsonic, and incompressible flow, which had been modeled by Navier stocks equations and $\kappa-\omega$ turbulence model or turbulent flow. The boundary conditions of the domain are as follows;

- Inlet velocity which is $30 \mathrm{~m} / \mathrm{s}$ with $\mathrm{Re}=3.72 \times 10^{5}$. With angles of attack values $\left(0^{\circ}, 4^{\circ}\right.$, $7^{\circ}, 10^{\circ}, 12^{\circ}, 15^{\circ}, 17^{\circ}$, and $19^{\circ}$.

- The outlet boundary is atmospheric pressure.

- Non-slip boundary conditions are on the wing and winglet.

- Symmetry boundary condition for other boundaries.

The second stage is the processing of the previous preparations. An iterative method was used to find the final results. The aerodynamic characteristics and flow field were evaluated continuously through these iterations to fulfill the final accuracy. The last stage is to evaluate the final characteristics and field parameters of the flow.

\section{EXPERIMENTAL WORK}

The previously discussed geometries of wing and winglet were manufactured using threedimensional printing technologies with plastic material as shown in Fig. 6. The aerodynamic characteristics were measured using a three-component force balance device. All the experimental tests were performed in a low- speed open-circuit wind tunnel with $(0.7 \mathrm{~m} \times 0.7 \mathrm{~m} \times$ $1.5 \mathrm{~m}$ ) rectangular test section. The contraction ratio of the wind tunnel is $9: 1$, which is designed by special equations of contraction. The maximum calibrated velocity is $55 \mathrm{~m} / \mathrm{s}$, for more details (Hussain, et al. , 2011) and (Hussain and Ali, 2014).

Three-component force balance is firmly installed outside the test section at three mounting points. The modified balancing consisted of three actuators; two lift actuators act vertically and the drag actuator which in the horizontal direction and passes through the axis of the model support. The actuators were connected by three load cells. The load cells were connected to digital weighing indicators SI 480 that can interpret and convert the analog signal to a digital format as shown in Fig .7. The calibration of the balance device without model had been done using calibrated weights with special mechanisms to transfer their effects in horizontal and vertical directions. 


Number $4 \quad$ Volume 26 April $2020 \quad$ Journal of Engineering

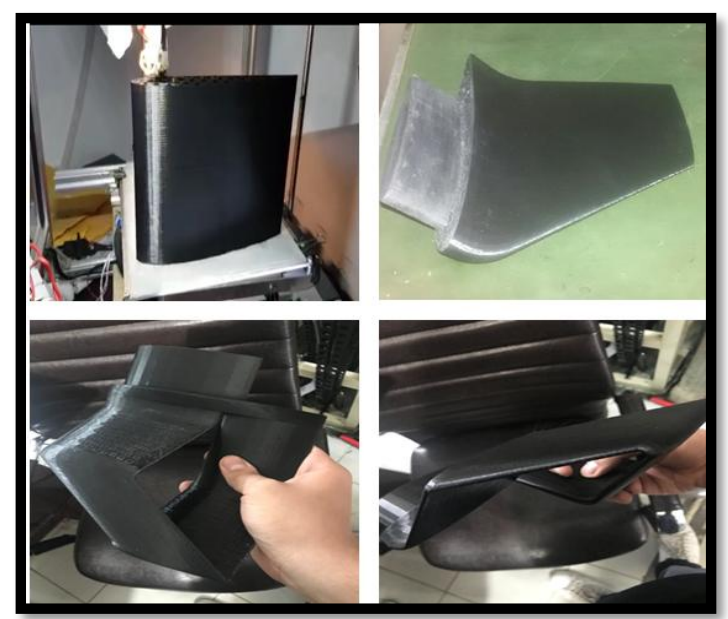

Figure 6. The wing model and the winglet.

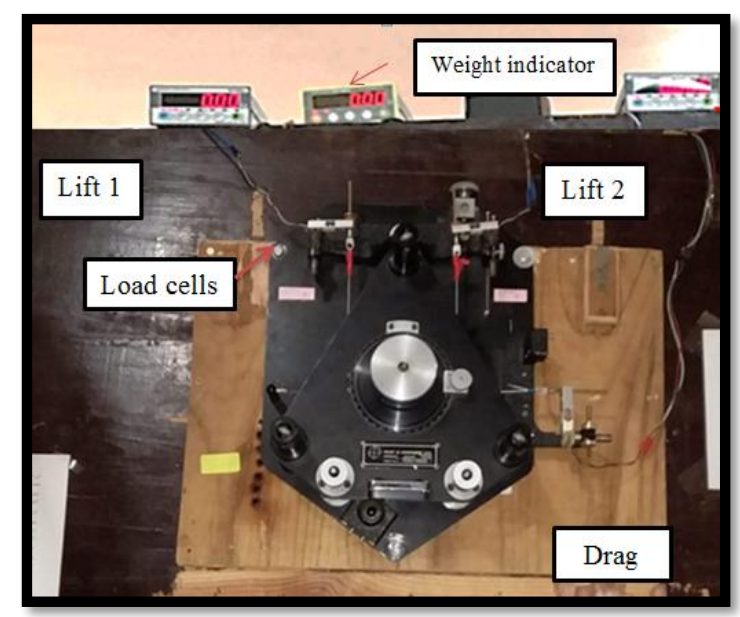

Figure 7. Three-component force balance.

The clear-wing and wing with winglets were installed by three-component balances at the root of the wing and placed inside the test section as shown in Fig $(\mathbf{8 , 9}$, and 10).

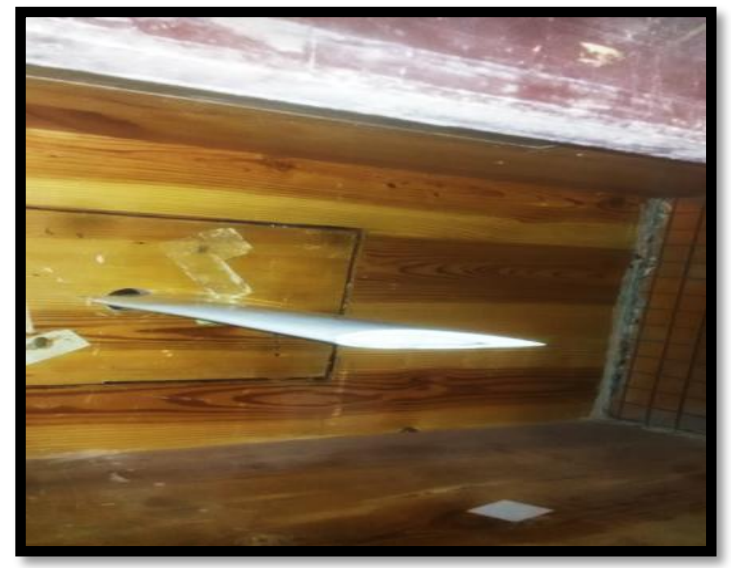

Figure 8. The clear wing inside the test section

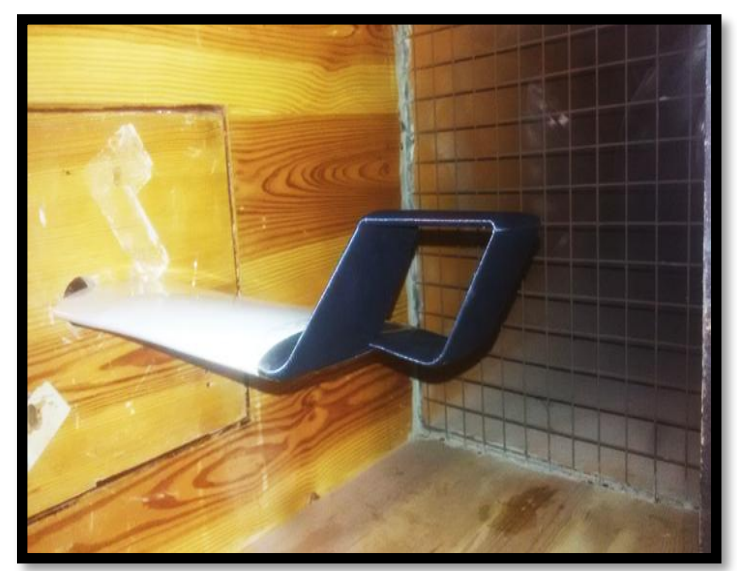

Figure 9. The wing with spiroid winglet inside the test section.

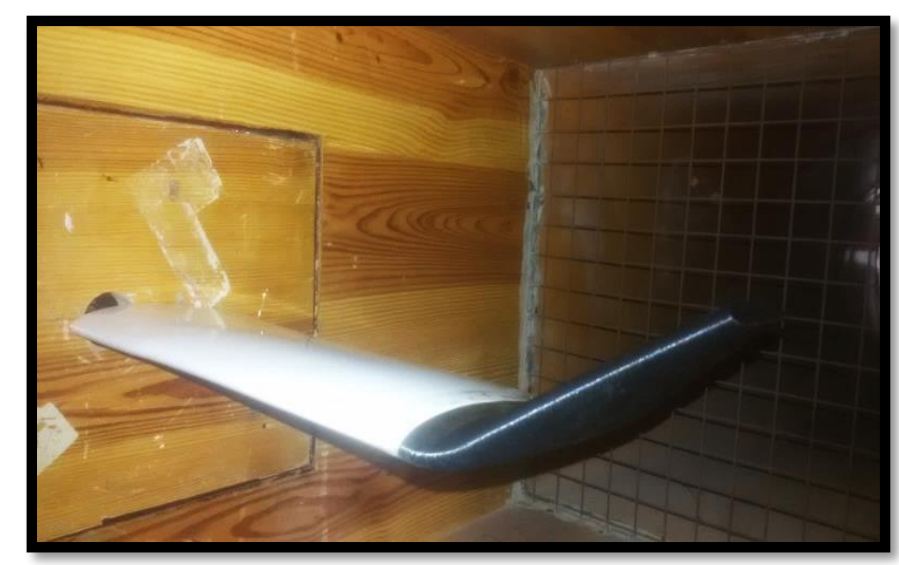

Figure 10. the wing with a blended winglet inside the test section. 
The lift, drag coefficients, and the pitching moment coefficients are given as follows;

$$
\begin{aligned}
& C_{L}=\frac{L}{\frac{1}{2} \rho_{\infty} v_{\infty}^{2} s} \\
& C_{D}=\frac{D}{\frac{1}{2} \rho_{\infty} v_{\infty}^{2} s} \\
& C_{M p}=\frac{M p}{\frac{1}{2} \rho_{\infty} v_{\infty}^{2} s c_{r e f}} \\
& C_{M b}=\frac{M b}{\frac{M b}{2} \rho_{\infty} v_{\infty}^{2} s c_{r e f}}
\end{aligned}
$$

where:

$\mathrm{L}$ is the lift, $\mathrm{D}$ is drag, $\mathrm{M}$ is pitching moment, $\rho_{\infty}$ : density of free stream $\left(\mathrm{kg} / \mathrm{m}^{3}\right) \mathrm{S}$ is reference area and $v_{\infty}$ velocity $(\mathrm{m} / \mathrm{s})$.

The testing free stream air velocity was $30 \mathrm{~m} / \mathrm{s}$, at the inlet of the test, the Pitot-Static tube and Micro-Manometer had been used to calibrate the speed of the flow. The experimental properties of air, temperature was (288K), pressure was (1 bar), and density was $1.225 \mathrm{~kg} / \mathrm{m}^{3}$.

\section{RESULTS AND DISCUSSIONS}

The lift, drag coefficient and pitching moment coefficient have been calculated from the numerical and experimental results. All results are conducted at Reynolds number $3.72 \times 10^{5}$ for clean wing and wing with two different types of the winglet for various angles of attack $0^{\circ}, 4^{\circ}$, $7^{\mathrm{o}}, 10^{\mathrm{o}}, 12^{\mathrm{o}}, 15^{\mathrm{o}}, 17^{\mathrm{o}}, 19^{\mathrm{o}}$.

\subsection{Lift Coefficient}

As shown in Fig.11 a traditional relation between lift coefficient and the angles of attack is noticed for the configurations (clearwing, wing with blended or wing with spiroid winglets).

The lift coefficient increases linearly for small angles of attack with an increase in the lift for spiroid and blended winglets compared to clearwing. It is clear that the blended winglet is more effective compared to the spiroid winglet for all range angles of attack.

The maximum lift coefficient shows that for blended winglets gives the highest value at $16^{\circ}$, while the spiroid winglet delays the stalling angle to $17^{\circ}$. This difference illustrates the uses of each type of winglets in aircraft.

The numerical lift coefficient has been verified by the experimental data which shows a good agreement between them for small to moderate angles of attack but in higher angles of attack, the results are somewhat deviated out, which may be attributed to the measuring system (threecomponent force balance) and its sensitivity to the alternative forces which is generated by the model. For different angles of attack, the blended winglet increased the experimental lift coefficient in about $6.17 \%$ to $33.3 \%$ as compared to the clearwing and the spiroid winglet is increased the experimental lift coefficient in about $3 \%$ to $23.37 \%$ as compared to the wing without winglet. 


\subsection{Drag Coefficient}

In Fig.12, the drag coefficient is illustrated for spiroid and blended winglets for different angles of attack. From the figure, the drag coefficient shows a parabolic increase with the angles of attack. For low angles of attack, the spiroid winglet has less drag coefficient than blended winglet, but when angles of attack have increased the value of the drag coefficient for the blended winglet decreased as compared to the clearwing and the wing with spiroid winglet.

The experimental drag coefficient is shown in this figure, which verifies the numerical results in highly matching data. The drag results show a reduction of about $2.78 \%$ to $24 \%$ for wing with spiroid winglet as compared to the clearwing for different angles of attack. The blended winglet reduced the drag coefficient of about $3.2 \%$ to $26 \%$ as compared to the wing without winglet for different angles of attack.

\subsection{Lift to Drag Ratio:}

To measure the efficiency L/D of the winglets an increasing in lift to drag ratio means that there is a reduction in drag force or increasing in lift force or both, thus the ratio may be represented by the aerodynamic efficiency of the geometry where the lift force is the output while the drag is the thrust input values. It is noticed that, at low angle of attack $\left(0^{\circ}-7^{\circ}\right)$, the blended winglet has the highest lift-to-drag ratio which is increased by $23.15 \%$ to $30.9 \%$ as compared to the wing without winglet and $2.48 \%$ to $15.38 \%$ as compared to spiroid winglet. For moderate angles of attack which is $10^{\circ}$ to $12^{\circ}$, the spiroid winglet has the highest lift-to-drag ratio which is increased by $40.8 \%$ to $45 \%$ as compared to the wing without winglet and $5.8 \%$ to $31.31 \%$ as compared to the blended winglet. At high angle of attack $\left(15^{\circ}, 19^{\circ}\right)$, the blended winglet is exceeded again with an increasing $52.3 \%$ to $67 \%$ as compared to the wing without winglet and $22.8 \%$ to $37.23 \%$ as compared to spiroid winglet as shown in Fig .13. Finally, angle $7^{\circ}$ is considered the best angle of attack.

Fig.13 also shows the experimental value of lift to drag ratio for the wing with and without winglet for different angles of attack. It is noticed that the CL/CD is increased by adding the winglet as explained in the numerical work. For low angle of attack, the ratio $\mathrm{C}_{\mathrm{L}} / \mathrm{C}_{\mathrm{D}}$ of wing with blended winglet is increased by $19.5 \%$ to $52.4 \%$ as compared to clearwing and for high angle of attack the ratio $C_{L} / C_{D}$ of wing with spiroid winglet is increased by $23.7 \%$ to $46.36 \%$ as compared to clearwing. The small discrepancy between the experimental and the numerical solution is noticed when compared to each other, which may be attributed to the accuracy of the experimental tests. Generally, a good agreement between the experimental data and the numerical solution is found as evident in the figure.

\subsection{Pitching moment coefficient}

The pitching moment coefficient at different angles of attack was presented and discussed in Fig.14. It is obvious that when the angle of attack increases, the pitching moment coefficient has been increased as shown in figure. When the winglet is added, the pitching moment coefficient is increased, which gave more stability to the wing. The blended winglet has the highest pitching moment coefficient, which is increased by (15.6\% to $27.73 \%)$ as compared to the clearwing, and $(0.877 \%$ to $16 \%)$ as compared to the wing with spiroid through different angles of attack.

The experimental pitching moment coefficient is presented in Fig.14, for different angles of attack. When the winglet has been added, same behavior of the numerical solution is noticed in the experimental tests. Where an increase in the pitching moment coefficient is noticed for 
blended winglets as compared to experimental wing without winglets for different angles of attack by a percentage range $10.9 \%$ to $24.6 \%$, and spiroid winglet is increased by $3.6 \%$ to $15.9 \%$ as compared to experimental wing without winglet.

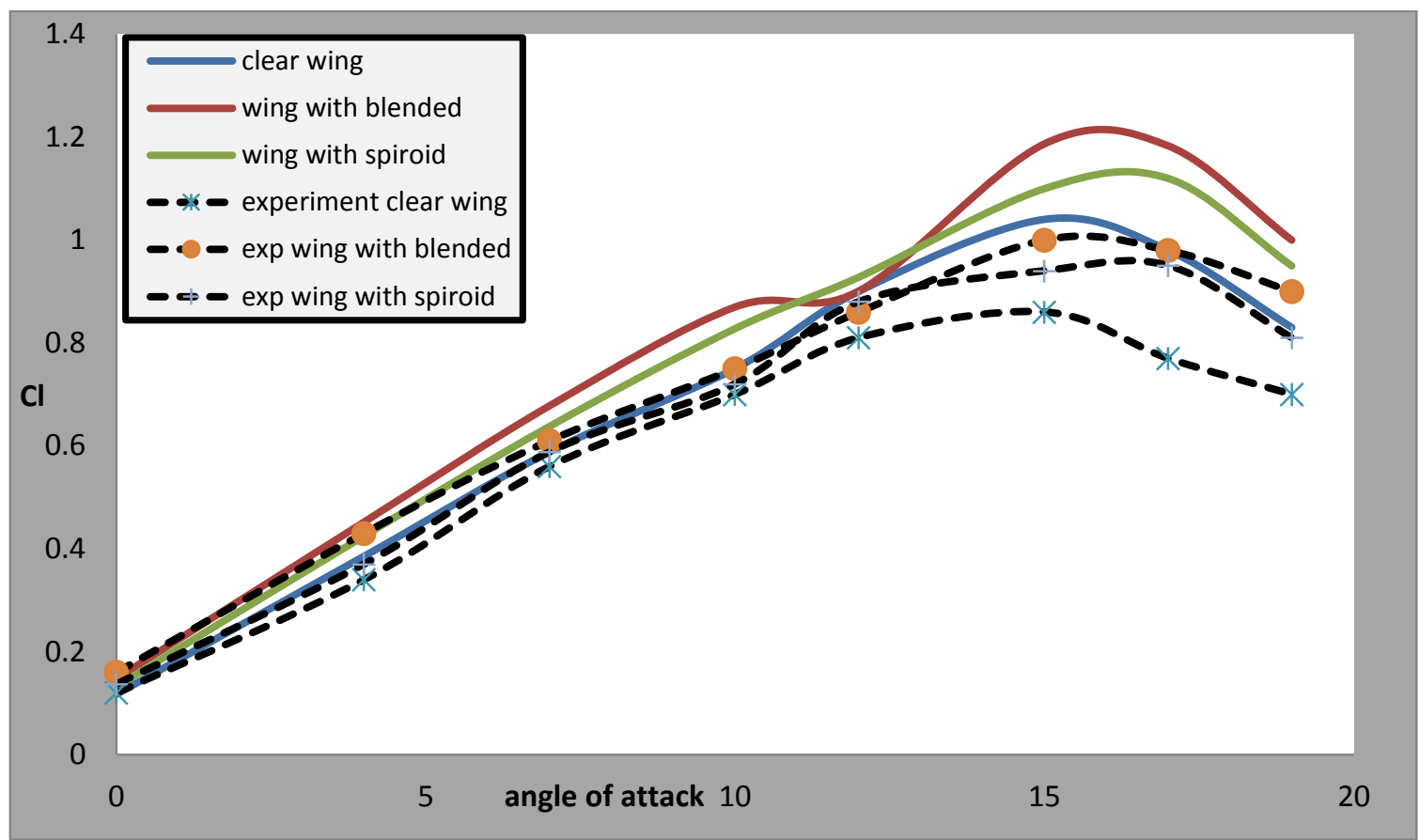

Figure11. Theoretical and experimental variations of lift coefficient versus angles of attack for wing/winglet.

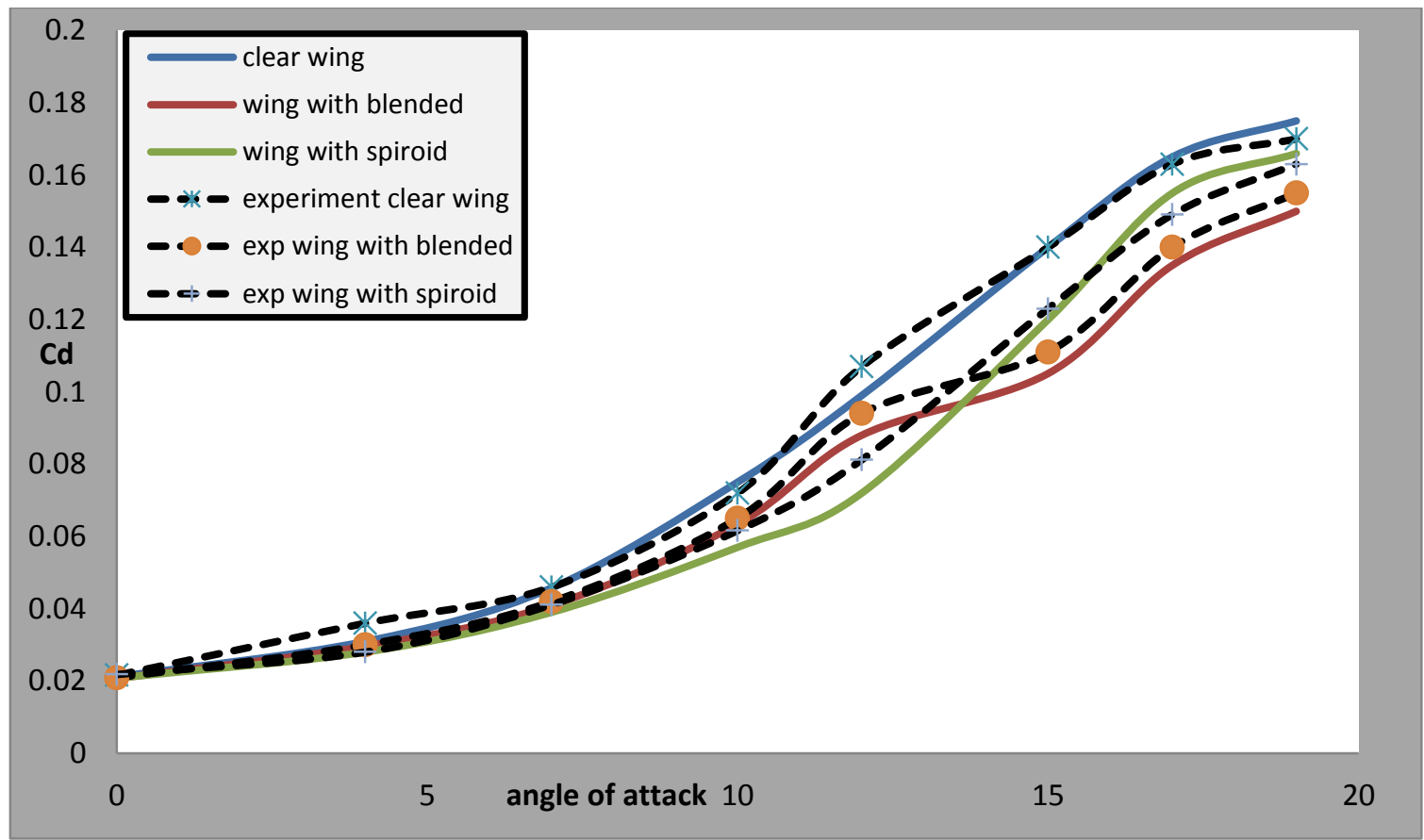

Figure 12. Theoretical and experimental variations of drag coefficient versus lift coefficient for wing/winglet. 


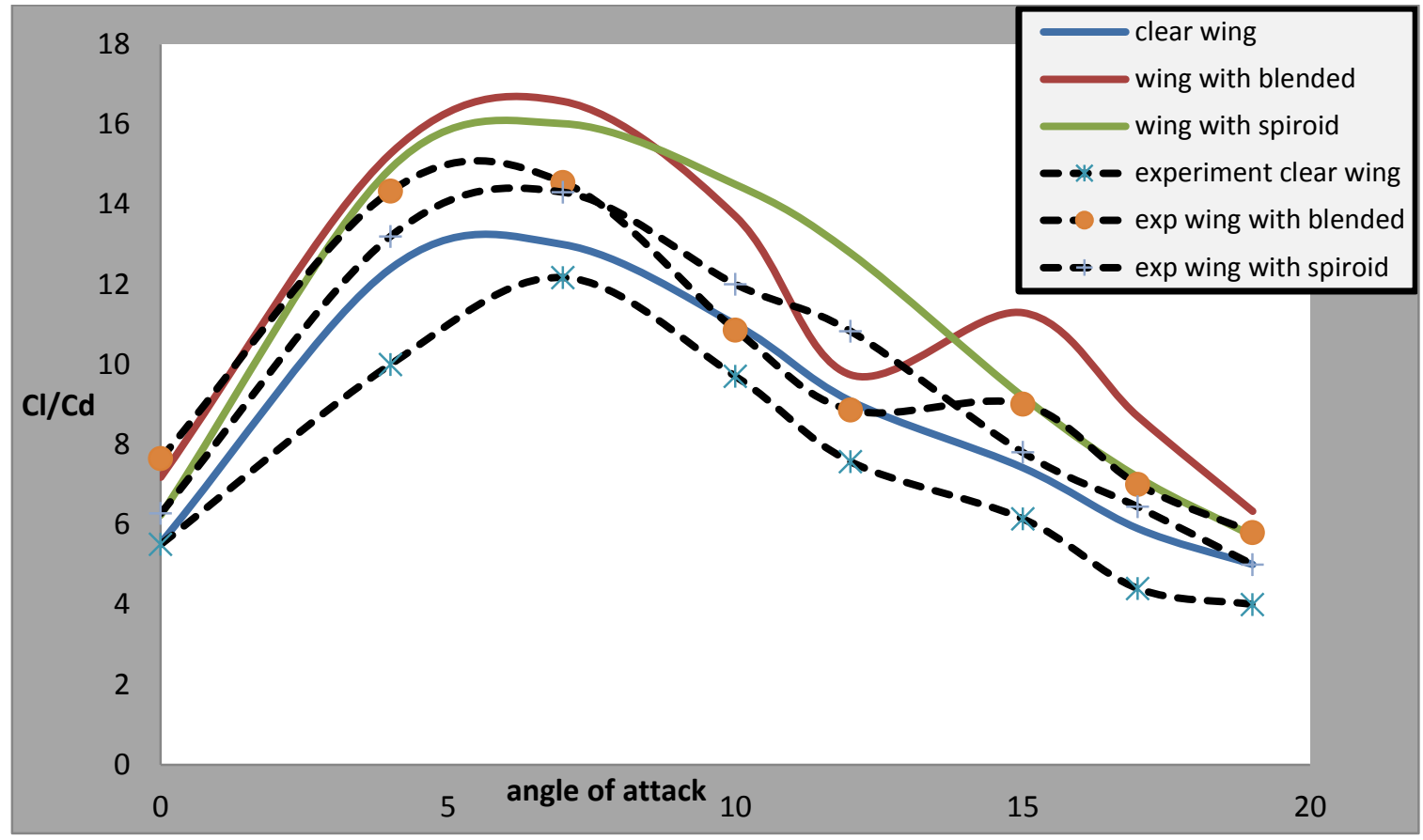

Figure 13. Theoretical and experimental variations of lift to drag ratio versus angles of attack for wing with/without winglet.

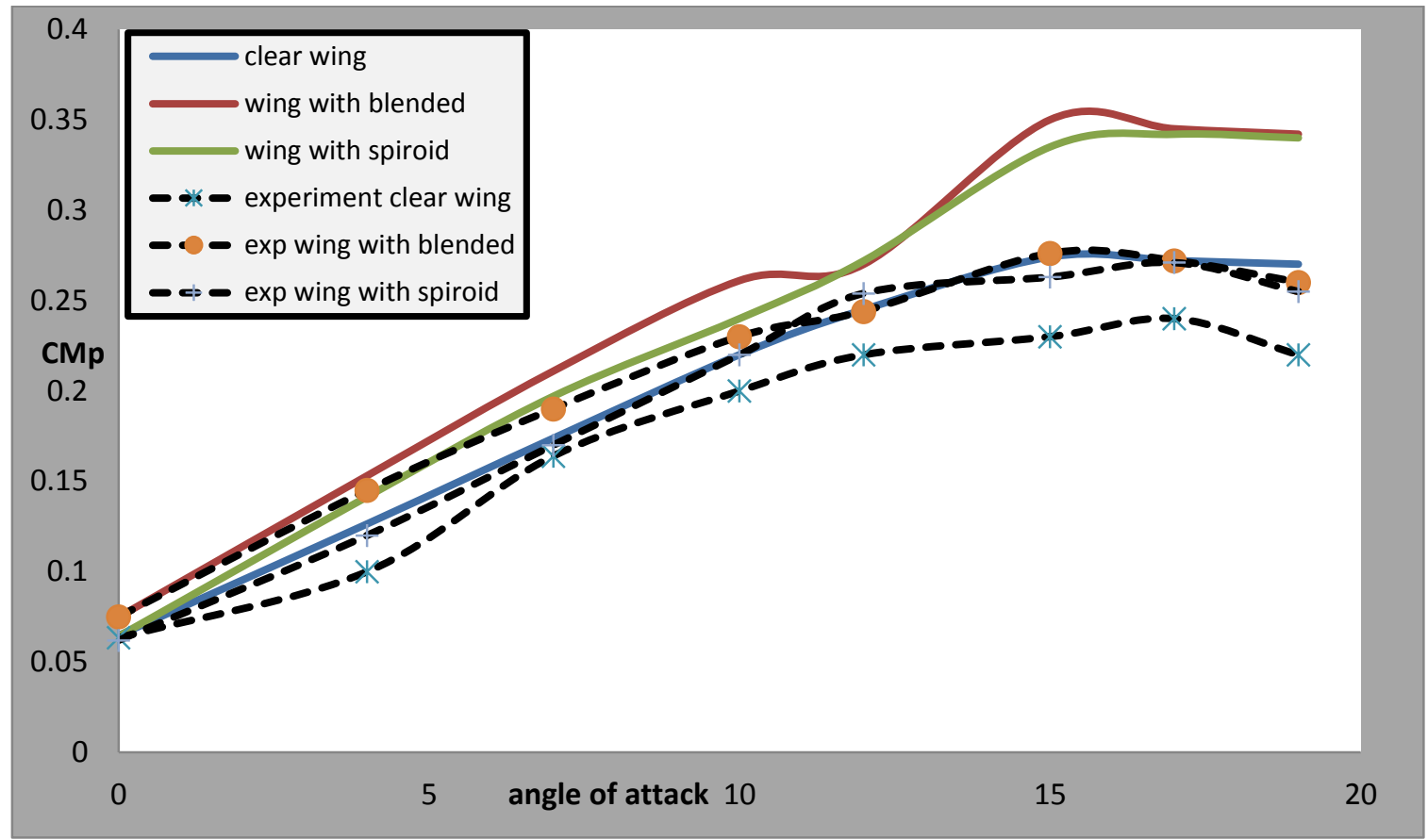

Figure 14. Theoretical and experimental variations of pitching moment coefficient versus angles of attack for wing with/without winglet.

\subsection{Flow Visualization}

The velocity vector, pressure contour and shear stress around the clearwing and the wing with winglet for $\left(0^{\circ}, 7^{\circ}, 15^{\circ}\right)$ angles of attack at $3.72 \times 10^{5}$ Reynolds number. The velocity vector is 
dense at the trailing edge of the clearwing, and the wing with winglet, the trailing vortices for the winglets are smaller than clearwing as shown in Fig 15. The winglets can reduce the wingtip vortices so that the winglet is acted as a barrier between low pressure and high-pressure sides of wing. The pressure contour on the clearwing and the wing with winglet are shown in Fig .16. It is obvious that the low-pressure coefficient is found at the leading edge on the upper surface. When the angle of attack is increased, the lower surface will be creating a higher static pressure. The wall shear stress is presented in Fig. 17 for $15^{\circ}$ angle of attack. The blue regions are that of zero shear stress which represents separation region especially at high angle of attack $15^{\circ}$. The maximum shear is found at the leading edge of the wing and winglets.

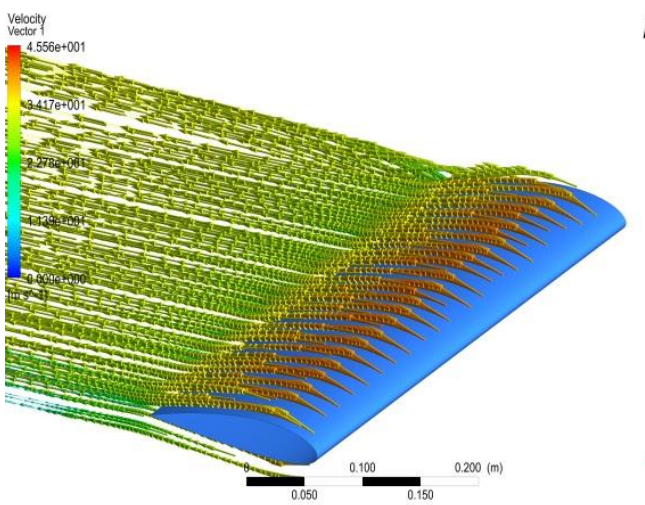

ANSYS

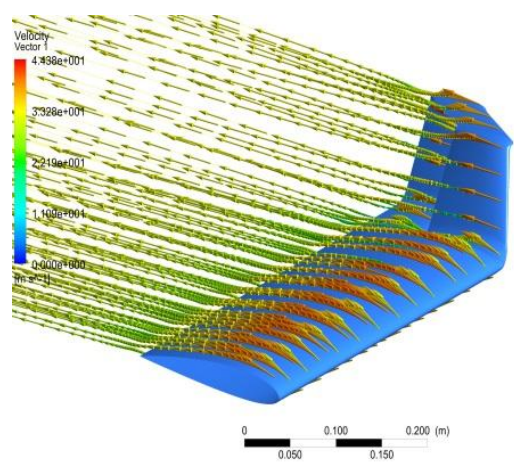

$\underset{\text { AN } 18.0}{\text { NSYS }}$

Figure 15. Velocity vector at $0^{\circ} \mathrm{AOA}$ without and with blended and spiroid winglet. 


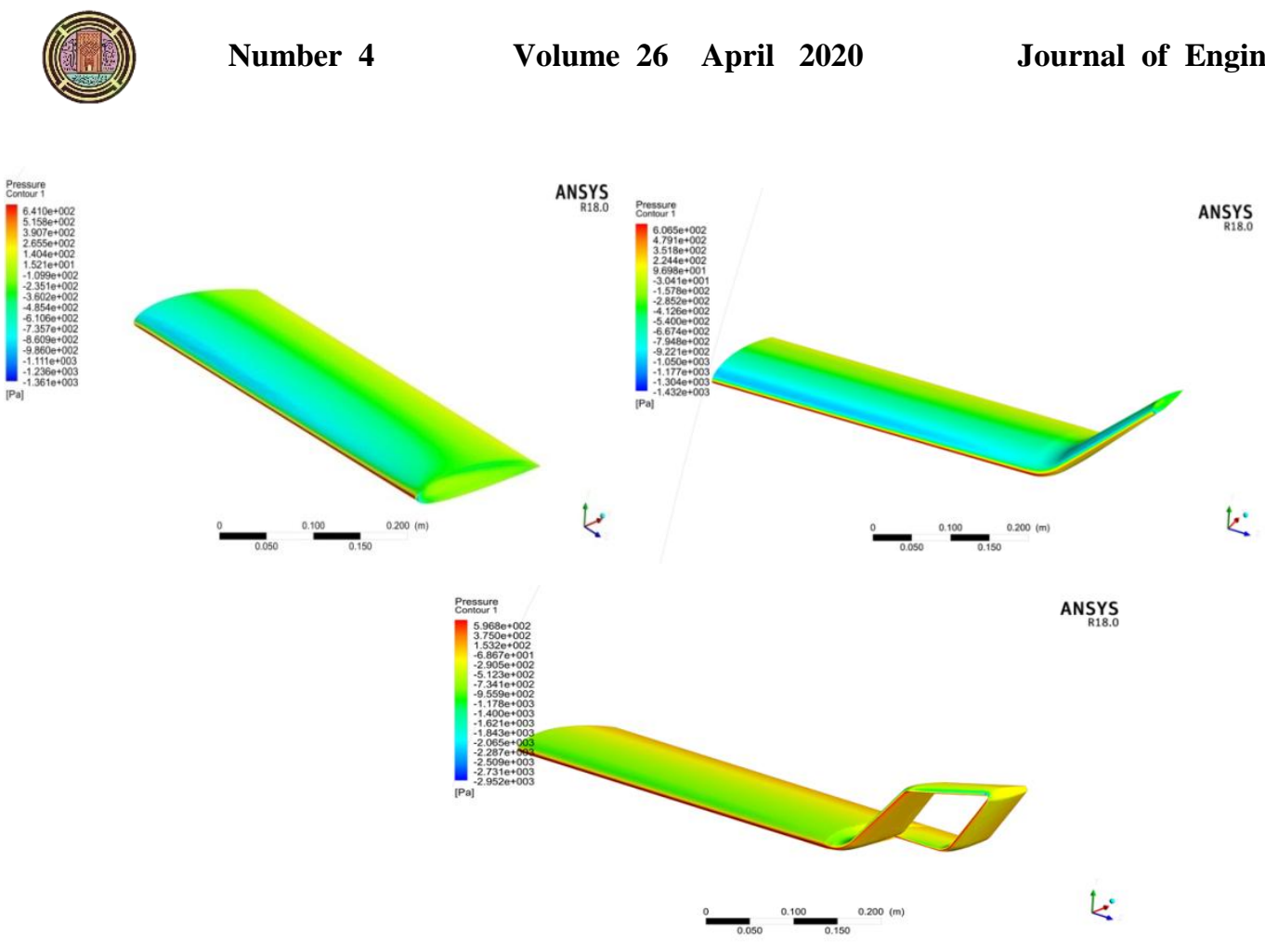

Figure 16. Pressure contour at $7^{\circ} \mathrm{AOA}$ without and withe blended and spiroid winglet.

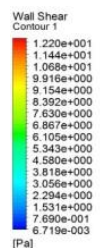

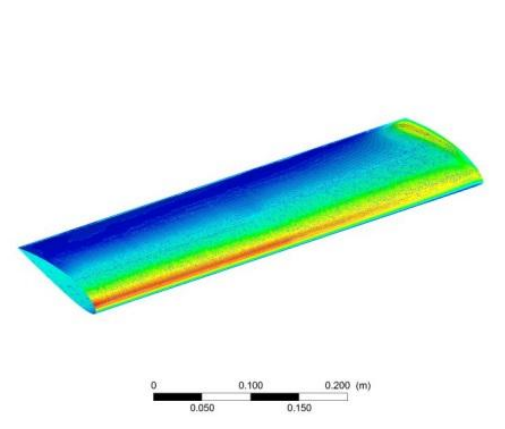

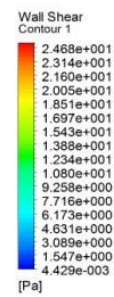

$\underset{\text { ANSYS }}{\text { R:B. }}$
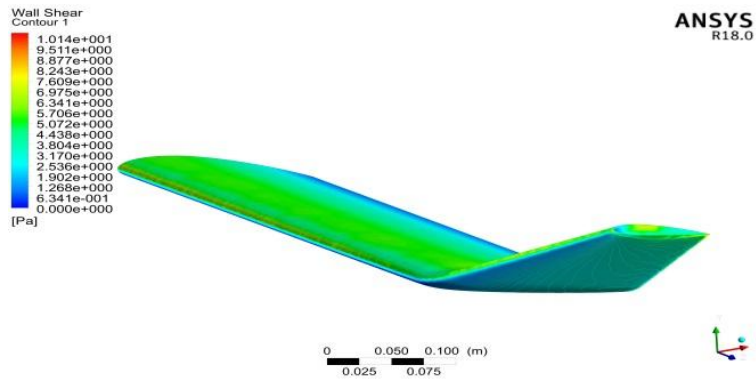

ANSYS
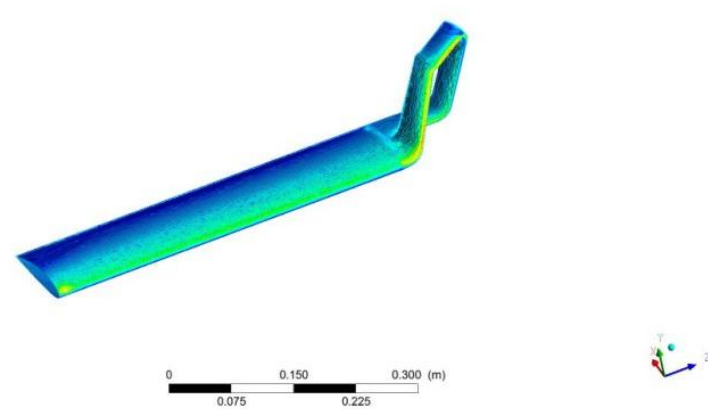

Figure 17. Wall Shear Contours at $15^{\circ} \mathrm{AOA}$ without and with blended and spiroid winglet.

\section{CONCLUSIONS}

The trailing vortices from the wing contribute aerodynamically by reducing the performance of the wing and also increases the induced drag. The winglet is used to reduce the vortex strength and induced drag. The spiroid winglet is dispersed vortices much faster than blended winglet. The performance increase can be seen in the ratio $C_{L} / C_{D}$, the blended winglet generates a lift to drag ratio of about (29.6\% to $66.6 \%$ ) more than the clearwing, and the lift to the drag ratio for the 
spiroid winglet is increased by $(8.5 \%$ to $45 \%)$ more than clearwing. The blended winglet is more stable as compared to others and increasing the stability of the wing by increasing the pitching moment at the leading edge which increased about (15.6\% to $27.73 \%)$ as compared to clearwing and $(0.877 \%$ to $16 \%)$ as compared to wing with spiroid winglet. So, in general, the blended winglet is better than the spiroid winglet.

\section{REFERENCES}

- Bada, V., Monika, K., Hussain, A., and Chikoti, P., 2016, CFD Analysis and Comparison of Spiroid and Dual Feather Winglets, Department of Aeronautical Engineering, Vardhaman College of Engineering.

- Beechook, A., and Wang, J., 2013, Aerodynamic Analysis of Variable Cant Angle Winglets for Improved Aircraft Performance, Proceedings of the 19th International Conference on Automation \& Computing, Brunel University, London, UK, pp.13-14 September.

- Guerrero, J., Maestro, D., and Bottaro, A., 2012, Biomimetic Spiroid Winglets for Lift and Drag Control, University of Genoa, Via Montallegro, C. R. Mecanique, pp. $34067-$ 80 .

- Helal, H., Khalil, E., Abdellatif, O., and Elhariry, G., 2016, Aerodynamic Analyses of Aircraft-Blended Winglet Performance, Journal of Mechanical and Civil Engineering (IOSR-JMCE), Vol. 13, Issue. 3, PP. 65-72.

- Hussain, H. Al-Kayiem and Chelven, A.K, 2011, An Investigation on the Aerodynamic Characteristics of 2-D Airfoil in Ground Collision, Journal of Engineering Science and Technology, Vol. 6, No. 3, P.P.369-381.

- Hussain, I. Y., and Ali, A. H., 2014, Calibration of Low-Speed Wind Tunnel (LSWT) Test Section, Journal of Engineering, University of Baghdad Dossier, No. ME-576.

- Shamil, P., Sanjid, M., Muhammed, E., Krishnan, A., and Jacob, T., 2018, Performance analysis of winglet by using CFD, International Research Journal of Engineering and Technology (IRJET), Vol. 05 Issue. 04, pp. 2395-0072.

- Soltani, M., Ghorbanian, K., and Nazarinia, M., 2004, Experimental investigation of the effect of the various winglet Shapes on the total pressure distribution behind a Wing, $24^{\text {th }}$ International Congress of the Aeronautical Sciences ICAS. 
NOMENCLATURE

\begin{tabular}{|l|c|c|}
\hline \multicolumn{1}{|c|}{ Description } & Symbol & Units \\
\hline Angle of attack & $\mathrm{AOA}$ & $/$ \\
\hline The bending moment about the x-axis & $M b$ & $\mathrm{~N} / \mathrm{m}$ \\
\hline Bending moment coefficient & $C_{m b}$ & $/$ \\
\hline Chord Length & $\mathrm{C}$ & $\mathrm{M}$ \\
\hline Density & $\rho_{\infty}$ & $\mathrm{kg} / \mathrm{m}^{3}$ \\
\hline Drag coefficient & $C_{D}$ & $/$ \\
\hline Drag force & $\mathrm{D}$ & $\mathrm{N}$ \\
\hline Free stream velocity & $v_{\infty}$ & $\mathrm{m} / \mathrm{s}$ \\
\hline Lift coefficient & $C_{L}$ & $/$ \\
\hline Lift force & $\mathrm{L}$ & $\mathrm{N}$ \\
\hline Pitching moment about z-axis & $M \mathrm{p}$ & $\mathrm{N} / \mathrm{m}$ \\
\hline Pitching moment coefficient & $C_{m p}$ & $/$ \\
\hline Reference area & $S$ & $\mathrm{~m}{ }^{2}$ \\
\hline Reynolds number & $\mathrm{Re}$ & $/$ \\
\hline Span & $\mathrm{b}$ & $\mathrm{m}$ \\
\hline
\end{tabular}

